Essay

\title{
Policy Discourses and Marginal Places: Histories of Environmental Democracy in India and Sweden
}

\author{
Seema Arora-Jonsson \\ Department of Urban and Rural Development, Swedish University of Agricultural Sciences, \\ Box 7012, 75007 Uppsala, Sweden; Seema.Arora.Jonsson@slu.se; Tel.: +46-18-671192 \\ Academic Editor: Rebecca R. Scott \\ Received: 11 July 2016; Accepted: 14 March 2017; Published: 17 March 2017
}

\begin{abstract}
Past decades have been marked with grassroots struggles around the use and access to natural resources such as forests, both in the global South and in the global North. On the one hand, we have politicians, bureaucrats and others needing to deal with these issues at the national and global level. On the other, we have the material practices and struggles at the local level as well as a parallel discourse on decentralization to local areas from the past few decades. By tracing the historical changes in policies that touch on forests-peoples relationships in India and Sweden, I contextualize these trends by placing them in a historical context and examine the questions that are central to a critical examination for environmental governance today. I analyze how environmental policy-making shaped forest politics in the two places and what spaces it provided for environmental democracy - especially in relation to possibilities for people's participation and for gender equality. I bring attention to the imperative to take account of questions of increasing expert dominance in environmental governance and local struggles, the space for local people's participation in forest and rural politics, the gendering of these spaces and relationships and how that affects environmental politics.
\end{abstract}

Keywords: environmental history; democracy; gender; Sweden; India; policy-making

\section{Introduction}

Forests have taken center stage in environmental policy with the threat of climate change. In addition to the importance of forests as resources, homes and livelihoods, forests are now also regarded as carbon sinks that could sequester carbon and halt climate change. The need to take action against climate change has galvanized policy makers, politicians, development and environment practitioners to pay attention to a global problem, and has put the spotlight on forests at an international level as well as nationally, both in India and Sweden.

At the same time, past decades have been marked by grassroots struggles regarding the use and access to natural resources such as forests, very much so in India and increasingly so in Sweden. On the one hand, politicians, bureaucrats and others increasingly feel the need to take decisions on forests and climate change at the national and global level. On the other hand, material practices of forest management and gendered struggles at the local level have contributed to a parallel discourse on the decentralization of environmental governance to local areas. How may these issues of scale be reconciled? The questions that are central to this paper concern the politics of scale and the implications of scalar politics for environmental democracy and local participation in forest management. How are these spaces and relationships gendered and how does that affect environmental politics and democracy on the ground? 
There is increasing consensus that environmental and gender politics are scalar and that their solution can no longer be envisioned at a single scale. This is considered to be very much a problem of our times. Yet, in this essay, I argue that we would be well-served to turn to history to examine issues of scale in relation to environmental democracy. In order to do so, I build on previous research with forest communities in India and Sweden involved in struggles over forest governance. My focus is on the policy background of their local struggles and their organizing. I analyze how environmental policy-making, both at the national level and through international agreements, shaped forest politics in the two places, how policy was implicit in constructing scale in relation to these places, and what spaces it provided for environmental democracy-especially in relation to possibilities for people's participation and for gender equality.

\section{A Relational Analysis across Scale}

This is not a conventional comparison between the two countries, but what I call a relational analysis. Rather than abstracting patterns, I examine the discourses that shape the specifics in the two countries and the complex circulation of ideas in a world with many links. I use the Indian case as a reference point to ask questions of the Swedish case that are not obvious at first glance. I do so both in relation to the empirical settings and in relation to the different theoretical frameworks generally associated with studies in two such different settings in the global North and the South. An important aspect of the relational analysis is to 'reverse the gaze' on questions of development and democracy in the global North, and Sweden in particular. Instead of assuming that development and gender equality are aspects that Sweden has reached in comparison with India, as is usually the case in mainstream development studies, I examine the ways in which these concepts are constructed in each place.

The parallel and relational reading of the history of forest and rural policies in the two places also brings to the fore the connections and differences between the two places. These connections are central to understanding contemporary life and processes of uneven development in the national context (that is, between the urban and rural areas), but also in international relations. Rural space played an important part in the conceptualizations of the two places as small, marginal places far from centers of official power and as 'out of the way' [1] of mainstream development. As I will show, the uneasy relationship of the 'rural' to the 'urban' and of people's relationships to government authorities outside their villages was evident in conceptualizations of place, as well as the appropriate scale for environmental governance. Relations vis-à-vis the state were not merely localized in relations between the modernizing state and its citizens, but went down to the depths of society [2], and gender was at the heart of these relations.

Corresponding to this are connections of scale. I use scale here not as a descriptive category or as given, but as a concept central to the politics of environments that changes across space and time. Scholars, especially geographers, have shown how scale, as a concept rather than pre-existing ontologically, is both socially and environmentally produced [3-7]. "The fundamental point being made is that scale is not necessarily a preordained hierarchical framework for ordering the world-local, regional, national and global. It is instead a contingent outcome of the tensions that exist between structural forces and practices of human agents" ([4], p. 220), producing not only social relations but also biophysical environments [3,6]. The constitution of scale is usually discussed as a 'politics of scale', and also raises concern about the constitution of various spatial levels and their relationships with each other [6]. As McCarthy writes, politics at or about a given scale are inseparable from politics concerning relationships among scales ([3], p. 738).

My focus here is on how environmental policy-making is implicit in these processes and embedded in the modalities of power. The focus on policy discourses highlights how state spaces are themselves dynamic and forged through ongoing engagements between agents, institutions and concrete political and policy circumstances. Thus, while policies in both India and Sweden developed in their own particular geographies, there were connections between them through institutions and actors that spanned these spaces, as well as travelling policy discourses that reached down into society and 
interacted with local gender relations. While I focus on the politics at particular scales, by bringing into tension two very different places, I also indicate the relationships among that may produce very different relations in in specific local spaces. In particular, I pay attention to the gendered politics that arise in delineating scale, in the making of marginality, of the nation-state or in commercial relations regarding land.

Several feminist geographers argue for a rescaling of the gender and environment literature to acknowledge the multiple ecologies that include habitat, home, household and the body, as much as the city, the region, the nation and the globe. In other words, gender matters at all these levels but importantly, as they note, these multiple ecologies are entangled in complex arrangements that can only be understood through their multi-sited and multi-scalar character [8]. This was clear in both study sites-in Nayagarh district in the state of Odisha in India and in the village of Drevdagen in the province of Dalarna in Sweden.

While beginning with the specifics in each case, I pay attention to the discourses that shape those specifics, that is, the complex circulation of ideas in a world with many links. It becomes clear how Nayagarh and Drevdagen experience the contingent history of complex power relations within their own countries and in relation to global scales. Thus, I first begin with a brief description of the two forest communities where I worked in order to ground the policy discourses in the two places. I then give a brief history of forest policies in these places. Studying the contexts together reveals the contradictions and similarities that emerge in the histories of state appropriation of land from communities in the 1800s, the importance of forests in the making of the nation/welfare states in the following period that witnessed state centralization in both countries, and eventually the move towards decentralization and privatization in the context of the neoliberal trends from the 1990s onwards. I conclude by looking at the present context of climate change and discuss some of the contradictions that become apparent in relation to aspirations for environmental democracy.

\section{Marginality: Two 'Out of the Way Places'}

The places where I worked were villages in Nayagarh district in Odisha (in periods between 1993 and 2000) and in the village of Drevdagen in western Sweden, in the mountains on the border with Norway (1998-2008). I describe both as 'out of the way places' [1], located within the boundaries of the nation-states but considered by the urban majorities to be isolated and peripheral.

Nayagarh district in the state of Odisha lies on India's eastern coast facing the Bay of Bengal. Odisha has a greater proportion of its population living below the poverty line than most other states in India. Most depend on forests and farming, although for most people, living off the land is a precarious occupation as their landholdings are very small. Differences in wealth are extreme. The villages in Nayagarh are mainly populated by what are called the 'general castes' - the khandait, chasa, kumithi, telegu - as well as the dalits. Odisha also has a large tribal population and their homes often lie in dense forests and mineral rich areas, coveted by the state and outside enterprise. As a result, tribal communities have witnessed their lands being expropriated by the state, mining companies or forest contractors, and not so infrequently tribal groups have been subjected to violence by authorities (see [9]). Several places in Odisha have also become the base for Maoist groups and have witnessed a great deal of violence.

Drevdagen is in the county of Dalarna in north-western Sweden. Depopulation since the 1960s has been a cause of considerable concern for rural areas in a major part of Sweden. These areas have modest service provisions such as public transport, postal systems, schools or shops, with few avenues of employment. There were strong feelings of being marginalized by central authorities among the people in Drevdagen. Their biggest regret was the fact that the forests and other natural resources from their environments are used to increase wealth in the cities, with the rural areas benefiting little from returns. In Drevdagen, most people did not depend on the forests directly for their livelihoods, like some groups did in Nayagarh, but the forests were very much a part of their social and cultural identities. Increasingly, they also realized that if they wanted to continue living in the countryside, 
which they did, they needed to be able to use the forests for their livelihoods, for example, in tourist enterprises. In both India and Sweden, the forests formed a very important part of people's lives and hopes for the future.

Local inhabitants in both Nayagarh and Drevdagen thus attempted to have a greater role in forest governance. In Nayagarh, since the 1980s, a community forestry movement called the BOJBP has spread across the entire district, resulting in a district-wide forest federation called the Mahasangha. By 2000, protection had resulted in considerable forest cover. In Drevdagen, villagers formed a village association to work towards, among other things, a greater say in the management of forests around their villages and for greater rights in relation to the forests. In both places, women found themselves outside of the decision-making processes in these organizations and chose to organize in their own groups. This resulted in fraught relationships in the villages and in forest governance. That is the subject of my book [10], but is not discussed here.

Here, I foreground the policy context of these local struggles and the similar situations in very different contexts in order to analyze parallels and differences, and how the rescaling of relations across time and space played a role in democracy on the ground. Although many of the events played out in similar ways, Nayagarh and Drevdagen are, nevertheless, different 'out of the way' places. The geographical setting, as 'out of the way' places, played an important part in their marginalization from what is perceived to be mainstream society. However, this marginalization was not only geographical-as I go on to show in the history I sketch out, it was a marginalization contested by people but also "developed in language in relation to state policies and regional politics." In various ways, "the authority of national policies was displaced through distance and the necessity of re-enactment at the margins" ([1], p. 27). Thus, when I refer to marginality, it has everything to do with power relations and social constructions of the geographical position. The scale at which people feel able to influence their lives plays an important part in conceptions of marginality.

There are different political and intellectual understandings of marginality. In both places, marginality developed in relation to particular political and urban cultures (imbued with power relations). However, there was the issue of 'marginality' in relation to an idea of development between the two places in the global North and South and a question of power in international relations. This is a question that assumes increased relevance today in the context of climate change-in whose responsibility it is, how it will be solved, and the importance of development vis-á-vis the environment.

My focus on negotiations of gender in these places is in the context of an asymmetry in relations of the communities with the various organs of the state. Gender (as power relations based on ideas about sexuality) was not something constructed within the communities before the community developed a relationship with the state. Marginality itself was gendered. Marginality, as the 'local and peripheral', intersected with gender in forming local processes regarding the forests, local management and development. I go on to show how this took place historically.

\section{History of State Appropriation of Forests}

On an all-India basis, the systematic public management of forests began in 1864 with the appointment of the first Inspector General of Forests. Simultaneously, a decision was taken by the colonial state to convert the forests into State Property. This conversion of forest land to State property continued after India's independence in 1947.

Historians working on Odisha have shown that despite the presence of shifting cultivators and the presence of the large number of people using the forests, documents describe the area as heavily forested and full of wild animals [11]. Yet, as scholars have shown, a narrative of deforestation was constructed in India that was used by the state to extend its authority in rural areas since the colonial period ([12], p. 20). The explanations given for deforestation are complex and have encompassed discussion of commercial interests, as well as destruction by local communities. Deforestation narratives were used as a description of an objective physical situation to justify 
intervention. This standard 'deforestation narrative' has submerged alternative constructions of the 'forest problem', and ignored the contributions of villagers in the care of the forests [12].

This narrative formed the basis of policy discourses that sought to delineate territory for the state. They gave rise to arguments against shifting cultivation in the 1800s both in India and Sweden that was meant to be halted by rational and scientific methods. In India, scientific forestry meant the institutionalization of certain territorial claims on the basis of timber quality. Forest lands were demarcated, with some being demarcated for the exclusive use of the forest department.

Tensions erupted as a result of this rescaling of territory. Delving into a range of official and other sources in Odisha, Pati shows how this was accompanied by increasing monetization that opened up a market in land in Odisha. There was an effort to induce forest dwellers to take up settled agriculture and to exact revenue on forest produce such as lac, hides, kendu and tendu leaves. This attempt at delineating the scale at which they could act led to a corresponding change in social relations. According to Pati, the peasantization of tribal communities that this entailed led to a process of Hinduization as they were tied closer to landowning classes. New taxes and the monetization of customary dues led to several rebellions and revolts by tribal communities and others who now had to pay revenue for customary rights that they had exercised for centuries. Those that came up against the colonial judicial structures were blamed for crimes against property and several communities were labeled as 'criminal tribes' [11].

There is little research on the effects that state policies have had on the gendered division of property and labor in Odisha except for peripheral references that provide some indications. Pati cites British reports from the colonial period that make references to changes in tribal lifestyles in Odisha. Greater monetization of local economies and the land market exacerbated social differentiation and gender inequalities. As tribal communities adopted Hindu customs and dowry transactions became more common, a man's wealth came to be associated with the number of wives he had. Daughters became expensive as communities were drawn into mainstream dowry practices and parents were subject to the vagaries of an uncertain market. There are mentions of female infanticide as well as witch-hunting ([11], pp. 33-34).

According to Agarwal, in the patrilineal system prevalent in most of India, historically, women appear to have had few individual claims to land. Yet in matrilineal societies, women inherited property and also enjoyed social independence and relative equality in marital relations. However, Agarwal notes that despite men's restricted access to property ownership in matrilineal systems, their rights of control over that property on the one hand, and their access to public bodies on the other (with links between those domains), often enabled them to consolidate substantial social prestige and political power. In addition, men's control of public decision-making gave them critical influence over the modification of legal and social rules, especially as conditions began to change in significant ways, particularly under British colonial rule. In short, ownership rights in landed property clearly conferred important benefits on women but their virtual exclusion from property management (in some groups) and from jural and overall public authority (in all groups) circumscribed the power that they could derive from those rights ([13], pp. 1466-67). It was clear that the scales at which men had access had an important bearing on power relations in the household, despite women's control over property in the private sphere.

\section{Timber and the Rescaling of Gender Relations}

Similar policy objectives prompted changes in forest lands and people's relations in Sweden. On his travels in Särna in Dalarna, Carl von Linné, known internationally as the father of taxonomy and ecology, wrote disapprovingly of the slash and burn practices of the inhabitants of this mountain area,

"Forest fires that raged several times had destroyed the great forest that lies between Åsarna and...from Särna...The earth was gone, little was green, instead, one stone on the other, as if the whole land was...mounds of stone. We had never before seen such badly managed forests, especially considering it was so large." 
Coming from Uppsala in the South and the seat of government, he rued that the forests were not being used for timber,

"The great forest, although so destroyed does the public no good with its wonderful timber for logs, masts and shipping." ([14], pp. 257-81).

This ignorance of timber that Linné writes about began to change from the 1800s. An increasing demand for timber, prompted to a large extent by the English ship-building industry and the need for charcoal, meant that the forests became a sought-after commodity, especially from the point of view of the crown. Changing gender relations were central to the policy changes that followed.

Historians in Sweden have argued that the importance assigned to timber by the state from the mid-1800s have overshadowed the important role that the forests and cattle rearing played in the local economy of the time $[15,16]$. Cattle rearing was women's work and, living in the summer farms in the forests, the women formed a close-knit female working culture ([16], p. 19). With the increasing importance of timber, work in the forests became the livelihood of many men who began to sell timber to the state and later to sawmill companies. Many summer farms in the forests began to be used by them instead. Work in the forest began to be associated only with timber extraction, and almost exclusively with young men who worked as lumberjacks, floaters and so on. Their work began to be regarded as 'real' forest work, and forest activities not associated with timber did not find place in the formal definition of forest use. This is also the case today and is a source of increasing conflict. These ideas of real forest work also became internalized by people in rural areas who downgraded their own activities in the forests (for subsistence or otherwise), and also began to conflate forest work with timber extraction [17], and a much wider scale of relations began to take hold and organize forest activities. In this rescaling and new definitions of forest work, women's work with cattle-rearing and berry and mushroom collection in the forests no longer found a place.

In tandem with a change in the forests, from being a female sphere to the construction of forests as a masculine domain, there was also a formalization of property rights. The state carried out what they called the storskifte, the great distribution of landholdings. Individual property rights were assigned while a great deal of land was also delimited for what were called kronoparker, or crown land. In fact, in Drevdagen, there are still people who claim to have deeds from the 1300s that show that the land that was appropriated by the state actually belongs to them. The move from collective ownership of property to individual property rights resulted in the consolidation of property rights mainly for men [18]. Thus, as the states gained power over the natural world, men in the communities gained property rights at the expense of women.

Incongruously, the commercialization and monetization that appeared to be taking hold in both places led to fairly different results, but in both places to the detriment of women. While in Odisha, women became 'expensive' and assumed characteristics of property themselves, the delineation of property rights in Dalarna began to slowly erode women's formal authority over land. The gap between ownership rights and managerial control have an important role to play in women's independence versus dependence on male relatives, both in India and in Sweden. Unfortunately, the dearth of research in this field in Odisha gives no indication as to how legal prescriptions have impacted on, or perhaps been subverted in everyday practice and gender relations. However, importantly, as Agarwal also points out, contestations over rights extend beyond households to encompass the complex institutions of community and state, to the arenas where decisions are made and unmade and need careful attention [13]. It is clear, however, that the rescaling of territory and relations with the state overlapped with the gendered division of property ownership and increasing division of the public and private sphere of the home and marriage. The new territorial power of the state in both countries laid the ground for the making of the nation-state in India and the welfare state in Sweden. 


\section{Nation-Making}

Common to nation-making in India after independence in 1947, as well as in Sweden in the post-World War II years, was the important role of policy-making in relation to natural resources such as forests. As suppliers of resources and raw materials, both the geographical spaces and peoples of Nayagarh and areas around Drevdagen were drawn into the project of nation-building. As the people in these areas became citizens with rights in a new nation in India and in the welfare state in Sweden, their marginality or peripheral status vis-à-vis the center was redefined ([10], p. 52). As the nation gained in importance, it "shifted the modalities of power, constructing new scales" [3] at which politics took place.

In India after independence, national interests overrode other considerations. This can be seen for example in the Indian Forest Policy of 1952 that states,

"The accident of a village being situated close to a forest does not prejudice the right of a country as a whole to receive benefits of a national asset" ([19], p. 29).

The displacement of communities from the forests for various developmental projects continued in independent India. The colonial state had laid the grounds for appropriating forest property. The new state continued with a fairly autocratic management. State investments in industrial infrastructure-power, minerals, metals, communications and forest-based industry-were provided to industry at highly subsidized rates and with virtually free access to crucial raw materials such as forests and water. Commercial forestry fueled conflicts not only between the state and commercial interests on the one hand, and the rural poor on the other, but also between settled cultivators and pastoralists as they clashed over diminishing resources [20].

However, several mobilizations contextualized demands for forests and land rights. As Jefferey and Sundar point out, it was impossible to turn a blind eye to the rights of villagers ([12], p. 18),

"the state and other actors have historically been forced to recognize the moral legitimacy of the claims of local people to have access to forests, often in response to movements of resistance. Even Forest Department Working Plans, geared towards maximization of revenue under the guise of 'scientific management' contained a symbolic nod towards accommodating local rights, in the form of a section on agricultural customs and wants."

These pressures forced welfare measures to be undertaken. Independent India attempted to set up mechanisms in the constitution that would democratize community institutions and allow local communities and tribal people to shape their own destinies. Nevertheless, the development paradigm that guided natural resource policy continued to govern management practices.

\section{The Making of the Glesbygd in Sweden}

Forest policy after World War II in Sweden aimed to increase the production of timber. This was the time of intense industrialization as the rest of Europe lay ravaged by war. This was also a period of rationalization and mechanization of forest and agriculture, and previous employment for men in forestry began to disappear. Seasonal work was replaced by annual contracts-the floating of logs began to be replaced by a network of roads.

Industrialization provided employment for many in the cities. In my interviews with villagers of Drevdagen, a narrative of a clear cause and effect emerged between state policy and the ensuing migration from the village. In the words of one of the inhabitants, who wrote a book on their fight to keep their village school when the authorities wanted to shut it down and for the children to travel to the neighboring town for schooling,

"The 1960s had barely begun when a very tangible worry began to infect the village population. When we eventually could decipher the authorities' and the media's message, we unwillingly worked out that we lived in the wrong place in our country...this 
propaganda was spread by the labor market authorities, who also had the requisite means to pressure people. Their "information" got absorbed to such a degree that the villager who chose to stay on risked being marked as backward, if he insisted on staying on in this out of the way spot and not catch hold of a sure chance in the big town!" ([21], p. 10).

People were given moving grants, flyttbidrag to move to urban centers. As the wave of industrialization subsided 'there were no matching moving home grants', said Gerd, a woman who had moved back to the village with her husband when the jobs in the cities dried up. Eventually, the depopulation of rural areas became a policy concern in the 1960s, especially as it coincided with the making of the welfare state. The migration of many women from rural to urban areas became a cause of alarm-especially in the media and in political debates.

Those who chose to stay on became citizens in marginal places. While the state sought to provide equal welfare for everyone, the price that these citizens had to pay was marginalization. The urban city was the measure-as can be seen in many policy areas. One such example was housing policy. While providing resources, the housing policy established a discourse on the right sort of standardized housing, whether it suited the terrain or not [22], and the right to describe what the rural problem was and what measures were needed was taken care of by the state. At the same time, all major investments were made in cities while rural areas were drained of natural resources that benefited mainly urban areas. Such measures have been regarded as a 'cultural disarming of the countryside' [23,24]. ${ }^{1}$

So, the glesbygd, translated literally as sparsely populated areas, came to be. However, for the urban mainstream, the glesbygd also came to be associated with the not so modern and backward periphery of the nation. Thus, glesbygd is not only a geographical naming but has layers of meaning. Like Gayatri Chakravorty Spivak's phrase for the 'third world' [25], the glesbygd in Sweden may be regarded as a proper name for a generalized margin. Paradoxically, the areas of the glesbygd were born out of a contradictory marginality: made marginal partly by attempts to bring these areas into the ambit of the welfare state. In other words, the urban context became the norm for these areas regardless of their own very different contexts and history. They became cast as the backward and marginal areas that, with active support from the state, were meant to 'develop' themselves in the mold of the urban cities. In the process, their own particularities and varied contexts were disregarded as uninteresting or backward. In contrast, in Nayagarh, marginality was constructed as a result of the inability of the state to reach these areas and provide services, despite the pervasive presence of various arms of government such as the forest department.

Nation-making redefined marginality in both contexts. From being marginal geographically, marginality became political, as these areas were drawn into the nation-state and its people became citizens in an 'out of the way' place in a reconfigured central state. In this rescaling of the nation, women acquired formal rights as equal citizens in both India and in Sweden. Citizenship meant acquiring new rights in a new nation, but it was also about needing to conform to the interests of the nation. This meant being displaced with little compensation, or dispossessed, as in many cases in India; or as in Sweden, being told how to live: the houses they could have, the work they could do, and as many in the village of Drevdagen argued, an estrangement from their environments-not being able to use the forests as they used to. While the geographical distance from the center of power in India did less to change local gender relations, nominally it opened up space for education for women and for them to be identified as independent citizens. It brought with it a repository of development programs aimed at them that created new relations and scales at which women and men would relate [26,27].

In Sweden, the welfare state opened up employment opportunities for women and they gained employment on a large scale. For women in the rural areas, these changes were double-edged. The expansion of the public sector professionalized a range of activities such as childcare, nursing

1 This has parallels to India today as surveys report that fewer and fewer young people want to stay on in agriculture and in rural India. 
and care of the elderly that hitherto had been carried out as unpaid labor in the home, traditionally by women. The public sector provided employment and hence economic independence in the larger struggle for gender equality. The disproportionate recruitment of women into public sector services was related to the fact that most men were already in the labor market. By the 1990s, Sweden had the highest female employment rate in the western world, at 85 percent. The employment rate for men was 90 percent. Extensive female labor market participation was a precondition for the formation of the welfare model ([28], pp. 81-83).

Progressive gender equality policies changed lives considerably. However, Sweden also has one of the most gender-segregated markets in the world with women in lower-paying professions and within the country, the most gender segregated labor markets were those in the western forest communities. In addition, a large part of the social infrastructure was maintained by women through unpaid labor within their family and circle of relatives, reflecting the existing relationships of power between the sexes ([28], pp. 43-45). Nevertheless, the public sector played an important role in deciding the level of freedom that the women have, and in gender relations.

Thus, at stake in both India and Sweden from the 1950s onwards was a concern for the welfare of the people; this was sought to be managed by improving national wealth through the control of natural resources, deploying forms of what Foucault [29] calls governmental rationality to manage processes and relations, all in the name of improvement of and for the population. As became apparent in the two study sites of Nayagarh and Drevdagen, this politics of marginalization was contested even as it was elaborated, and a reluctant acceptance of belonging to a nation or a welfare state from which they benefited was in constant tension with an intransigence among the people vis à vis state authorities, occasioned by their marginality.

It was a marginalization developed in language (the glesbygd or contrarily the ban jatis or forest castes as the communities in Odisha went on to call themselves), in dialogue with state policies and regional politics, rather than in their isolation from what is perceived as mainstream society. For women in India, however, deep-seated cleavages of caste and class became ever more important as they intersected with gender, and determined women's access to public services and the environment. In the more equal Sweden, discourses on gender equality and progressive policies at the national level opened up new opportunities for women. Incongruously, this assurance of gender equality had unexpected consequences for gendered environmental relations, as I show next.

\section{Local Participation and Democracy}

The 1990s were a decade of state decentralisation both in India and in Sweden. Policies were adjusted to 'market forces' and global processes were complicit in reorienting notions of the rural community, and in shaping people's access to and control over natural resources and local development. At the same time as important decisions over the environment were taken in distant places, there was also a shift in policies towards people's participation and gender equality in the management of natural resources and local development. People were increasingly expected to take responsibility for the welfare of their own communities. Policies in both countries evolved in the context of a growing consensus among international aid agencies and among some governments, both in the global North and the South, that endorsed local management or participation as the paradigm for the sustainable development of rural areas and forests, regarded as "a paradigm shift in questions of resource management" [30].

Thus, the period of centralization until the 1980s eventually gave way to a process of decentralization both in India and in Sweden. In India, the Panchayati Raj Act in the 1990s devolved power to local village councils or the gram panchayats with mandatory representation of women. In Sweden, a transfer of political power down to municipalities characterized the political process. Previous regional policy, envisaged as equal development for all, changed to a new approach that emphasized competition between regions for development funds through a focus on public, private 
and civil society involvement. Public services in rural areas continue to be cut down and privatized, or handed over increasingly to people to manage through 'projects' [31].

In the field of environmental governance, community management of forest resources in India became an accepted element of the discourse on forestry, leading some researchers to ask if this was indeed a 'new moral economy' for India's forests [12]. While there were several attempts by the government and non-government organizations such as Joint Forest Management Programs in Odisha, there was also a dynamic local community forestry movement that was taking shape. Many such movements and events all over the country can be seen to have laid the ground for the Forests Rights Act that was finally passed in 2006, acknowledging the rights of forest dwellers.

In academic and policy circles, these local movements were hailed but they also engendered a debate on unequal gender relations. It became clear that the groups which hoped to herald a new form of local environmental democracy were far from democratic. Women in particular were excluded in different ways: either physically absent from local forest management forums [32-34] or finding it difficult to influence the decisions taken even when present [10]. It appeared that the goals of environmental sustainability and local democracy may well be undermining those of gender and social equality and entrenching inequalities. Gender aspects, such as the insistence that women and women's groups be considered in forestry discussions, became an important component of project support for community forestry groups with varied results (see [10]).

Swedish development aid (Sida), through their support to Oxfam, supported social forestry programs and the need to take into account gendered concerns, for example, in the community forestry movement I worked with in Odisha. Especially in the 1990s, the Swedish state saw itself as a proponent of gender equality, not only within the country, but Swedish officials worked actively to lobby for greater attention to questions of gender and participation in international arenas. In Sweden, the discussion on forests was limited to the environmentalists who argued for nature conservation goals and the forest sector, mainly concerned with the production of timber. Eventually, in 1993, forest policy that had one overriding goal of timber production was forced to accommodate environmental goals. Discussions continue to center on the close-to-hostile relations between environmentalists and proponents of commercial forestry (the foresters and forest companies). In this polarization between the environment and forest production aims, social and gendered aspects that concerned forest communities and their livelihoods find little place in policy. Although there are references to 'social values' of forests, these are limited to seeing forests as spaces for recreation and sport, again being an urban perspective on forests.

The issues that the people in Drevdagen spoke about, of wanting to use the forests to sustain livelihoods, have not been a part of these debates. Voices outside of the production versus environmental debates are largely drowned out in the noise of production and environmental goals in policy making, but also in research, with one or two exceptions in the past [35]. However, the scholarship on conflicts at the local level has increased in recent times [36,37]. All these bring attention to controversies on the ground with people who have resisted decisions on clear cuts and logging of the forests around their villages, contested the construction of nature reserves, and those who have demanded to be included in decision making on the environment. These have also raised the question of what and who the forests are really for [10].

Ideas about people's participation made an inroad into a different policy discourse, that of environmental policy. The white paper on environmental policy called for 'innovative methods of local management with the participation of different groups' ([38], p. 85). Since then, a number of pilot projects have been initiated and policy discussions have begun to pay heed to the idea of people's participation, at least in policy rhetoric. There have been initiatives in varied sectors such as fisheries and even in the management of a nature reserve, but on the whole the forest sector has kept out of these debates. Interestingly, some of these changes in policy have been catalyzed by bureaucrats and practitioners who had formerly been working in an international and development context in the South and who were now involved in environmental issues in Sweden. 
However, a corresponding debate on gender and local participation such as in India was singularly absent in Sweden. The lack of attention to gender inequalities in the forest sector was also brought up in a government report that criticized the forest sector for being painfully slow in attempts at establishing gender equality within forest activities [39]. The discourse on having achieved democracy and gender equality precluded the need to consider those issues within Sweden, despite research that pointed to gendered discrimination and inequalities in these areas [40]. In 2011, for the first time, a document on gender equality was produced for forest policy [41], although rather than gender equality, the focus was on how gender equality itself and women's entrepreneurship could be harnessed for the forest sector.

\section{A New Climate for Environmental Democracy?}

Contextual histories made up forestry science both in India and in Sweden while they also related to certain 'connecting' ideas. This is all the more pertinent in the emerging 'global' discourses on the current environmental focus that is linked closely to the question of forestry-the problem of climate change. Changing relations of scale were evident over three periods in different ways in the two countries. These changes of scale and shifting of the borders of what was 'local' were evident in the shift away from localized control over resources as in Sweden, or from patron-client relations as in India, with increasing commercialization. Borders were once again redefined and rescaled with the making of the nation-states in both places. These engendered a new and different scale of relations within communities and with those outside, as people accepted and contested these changes, thus redrawing the borders of their environments. Disciplinary relations were not merely localized in relations between the modernizing state and its citizens, but went down to the depths of society [2] and gender, and power relations on the ground changed in tandem with state-people relations. As I discuss elsewhere [10], the forms they took and the resistance they engendered, as well as its consequences, varied and could produce unexpected results.

Today, it appears that an increased scramble for resources worldwide, and the ways in which climate change is being handled-centered in university labs and in the complex measurements of carbon stock, as well as in international negotiations, threatens to undermine previous decades of peoples' movements. Policy coordination with actors such as non-governmental organizations (NGOs), business organizations, and multinational organizations is considered inevitable, and there is a great deal of emphasis on 'governance' that includes a range of actors besides the government. However, while previously the word 'participation' could imply local communities, now the participants (large NGOs, companies and others) are often one step removed from the environments themselves and are found in the rarefied settings of offices and conference rooms of public and private bodies. This brings a new scalar politics to bear and at a larger scale compared to earlier.

The attention to climate change has furthered the push towards new kinds of knowledge production that Mike Hulme calls "a managerialism on a planetary scale" ([42], p. 561). Once again, as research shows, the current landscape of industries, governments and other bodies with a say in these issues is predominantly male [43]. Further, women in climate change discourse are assigned only two possible positions - either as most vulnerable or as virtuous and caring for the environment. Instead of addressing gender as questions of power, gender is equated with women [44]. Despite pronouncements at international levels about needing to face climate change together as a global environmental problem, climate change has brought to the fore divides between the global North and South. Questions of historical injustices and responsibility assume importance as nation-states stake their rights to a common atmosphere and the right to 'develop.'

What then are the scalar implications for participation in local environmental democracy as new actors and interests enter the scene? It is clear from the histories outlined here that the scale at which decisions are made over the environment can quite suddenly be changed and determined by outside forces. At the same time, this does not happen in isolation. As the community forestry groups in India and in Odisha in particular showed, they too can rescale the spaces at which questions on the environment are taken up. Through their networks and activism, they pushed policy to acknowledge 
their space and redesigned state and space relations, and this creation of new scales was always in tension with relations of gender. In Sweden, on the other hand, the close presence of the welfare state, even in the periphery of the nation, maintained the scale of the nation-state much more firmly, although it is increasingly being eroded as new actors and international and EU policy-making on climate change makes intrusions into the national scale.

According to Sheila Jassanoff, "Living creatively with climate change will require re-linking larger scales of scientific representation with smaller scales of social meaning" [45]. How will this knowledge be reconciled? How is democracy to be ensured and particular interests to be recognized? These are the questions that confront us today, both in Sweden and in India and they need much more of our attention, especially in relation to their gendered repercussions.

Acknowledgments: This paper draws on work previously published in my book, Gender, Development and Environmental Governance: Theorizing Connections [10].

Conflicts of Interest: The author declares no conflict of interest.

\section{References}

1. Tsing, Anna Lowenhaupt. In the Realm of the Diamond Queen. Princeton: Princeton University Press, 1993.

2. Foucault, Michel. Discipline and Punish: The Birth of the Prison. New York: Vintage Books, A Division of Random House, 1979.

3. McCarthy, James. "Scale, Sovereignty, and Strategy in Environmental Governance." Antipode 37 (2005): 731-53. [CrossRef]

4. Marston, Sallie A. "The social construction of scale." Progress in Human Geography 24 (2000): $219-42$. [CrossRef]

5. Marston, Sallie A., and Neil Smith. "States, scales and households: Limits to scale thinking? A response to Brenner." Progress in Human Geography 25 (2001): 615-18. [CrossRef]

6. Görg, Christoph. "Landscape Governance: The 'politics of scale' and the 'natural' conditions of places." Geoforum 38 (2007): 954-66. [CrossRef]

7. Engel-Di Mauro, Salvatore. "Seeing the local in the global: Political ecologies, world systems and the question of scale." Geoforum 40 (2009): 116-25. [CrossRef]

8. Hawkins, Roborta, and Diana Ojeda. "Gender and environment: Critical tradition and new challenges." Environment and Planning D: Society and Space 29 (2011): 237-53.

9. Padel, Felix, and Samarendra Das. Out of this Earth: East India Adivasis and the Aluminium Cartel. Hyderabad: Orient Blackswan, 2010.

10. Arora-Jonsson, Seema. Gender, Development and Environmental Governance: Theorizing Connections. London: Routledge, 2013.

11. Pati, Biswamoy. Resisting Domination: Peasants, Tribals and the National Movement in Orissa 1920-50. New Delhi: Manohar, 1993.

12. Roger, Jefferey, and Nandini Sundar, eds. A New Moral Economy for India's Forests? Discourses of Community and Participation. New Delhi, Thousand Oaks and London: Sage, 1999.

13. Agarwal, Bina. A Field of One's Own: Gender and Land Rights in South Asia. Cambridge and New Delhi: Cambridge University Press, 1994.

14. Von Linné, Carl. “Iter Dalekarlicum.” In Carl Von Linnés Ungdomskrifter. Stockholm: K. Vetenskaps-Akademien. Andra Serien, 1734, pp. 233-67.

15. Montelius, Sigvard. "Dalarnas Skogar: En ekonomisk-historisk rapsodi." In Dalarnas Hembygdsbok. Falun: Dalarnas fornminnes-och hembygdsförbund, 1977, pp. 1931-93.

16. Montelius, Sigvard. Fäbodväsendet $i$ Övre Dalarna. Stockholm: Akademilitteratur, Gotab Stockholm, 1977.

17. Kaldal, Ingar. "Skog, arbeid og dagligliv i kvinners og mens fortellninger fra Trysil og Nord-Värmland etter 1930." In Skogsliv: Kulturella Processer i Skogsbygden. Edited by Ingar Kaldar, Ella Johansson and Hanna Snellman. Lund: Historiska Media, 2000.

18. Niskanen, Kirsti. “Husbondeväldets röst: Äktenskap, egendom och kön under första delen av 1900-talet." In Kvinnor Och Jord: Arbete och Ägande från Medeltid till Nutid. Edited by Britt Liljewall, Kirsti Niskanen and Maria Sjöberg. Stockholm: Nordiska Museet, 2001. 
19. Government of India. "National Forest Policy. Ministry of Food and Agriculture Resolution. New Delhi, 12th May, 1952." Available online: http://circle.forest.kerala.gov.in/tckollam/images/docs/policies/ nfp1952forest.pdf (accessed on 17 March 2017).

20. Gadgil, Madhav, and Ramachandra Guha. The Use and Abuse of Nature (Incorporating This Fissured Land, an Ecological History of India and Ecology and Equity). New Delhi: Oxford University Press, 2004.

21. Halvarsson, Hans. I Demokratisk Ordning Beslutat. Stockholm: Författares Bokmaskin, 1999.

22. Ingar Kaldal, Ella Johansson, and Hanna Snellman, eds. Skogsliv: Kulturella Processer i Nordiska Skogsbygder. Lund: Historiska Media, 2000, pp. 118-44.

23. Allardt, Erik. Att ha att Älska Att Vara: Om Välfärd $i$ Norden. Lund: Argos Förlag AB, 1975.

24. Frånberg, Gun-Marie. Kvinnliga Eldsjälar i Glesbygd: Lokal Mobilisering, Förändring och Anpassning. Östersund: Glesbygdsmyndigheten, 1994.

25. Spivak, Gayatri Chakravorty. "Poststructuralism, Marginality, Postcoloniality and Value." In Literary Theory Today. Edited by Peter Ollier and Helga Geyer-Ryan. Oxford and Cambridge: Polity Press, 1990, pp. $219-44$.

26. Lingam, Lakshmi. "Taking Stock: Women's movement and the State." In Social Movements and the State. Edited by Ghanshyam Shah. New Delhi, Thousand Oaks and London: Sage Publications, 2002, pp. 310-34.

27. Sharma, Aradhna. "Crossbreeding Institutions, Breeding Struggle: Women's Empowerment, Neoliberal Governmentality, and State (Re)Formation in India." Cultural Anthropology 21 (2006): 60-95. [CrossRef]

28. Forsberg, Gunnel. Könskvotering i Regionalpolitiken-Förslag till Framtida Åtgärder. Uppsala: IM-Gruppen i Uppsala AB, 1999.

29. Foucault, Michel. "Governmentality." In The Foucault Effect: Studies in Governmentality. Edited by Graham Burchell, Colin Gordon and Peter Miller. London: Harvester Wheatsheaf, 1991, pp. 87-104.

30. Shackleton, Sheona, Bruce Campbell, Eva Wollenberg, and David Edmunds. Devolution and Community-Based Natural Resource Management: Creating Space for Local People to Participate and Benefit? London: Overseas Development Institute, 2002.

31. Arora-Jonsson, Seema. "The realm of freedom in new rural governance: Micropolitics of democracy in Sweden." Geoforum 79 (2017): 58-69. [CrossRef]

32. Agarwal, Bina. "Gender inequality, cooperation and environmental sustainability." In Inequality, Collective Action and Environmental Sustainability. Edited by Jean-Marie Baland, Samuel Bowles and Pranab Bardhan. New York: Russell Sage, 2003.

33. Sarin, Madhu. Who Is Gaining? Who Is Losing? Gender and Equity Concerns in Joint Forest Management. New Delhi: Society for the Promotion of Wasteland Development, 1998.

34. Sarin, Madhu, Neera M. Singh, and Nandini Sundar. Devolution as a Threat to Democratic Decision-Making in Forestry? Findings from Three States in India. London: Overseas Development Institute, 2003.

35. Jensen, Ebba Lisberg. Som Man Ropar i Skogen: Modernitet, Makt och Mångfald i Kampen om Njakafjäll och i den Svenska Skogsbruksdebatten 1970-2000. Human Ecology. Lund: Lund University, 2002.

36. Eckerberg, Katarina, and Camilla Sandström. "Preface to Forest Conflicts: A Growing Research Field." Forest Policy and Economics 33 (2013): 3-7. [CrossRef]

37. Lindahl, Karin Beland. Skogens Kontroverser: En Studie om Plats och Politik i Norra Sverige. Stockholm: Institut för Framtidsstudier, 2009.

38. Miljö- och energidepartementet (Ministry of Environment and Energy). "En Samlad Naturvårdspolitik. Skr. (2001/02:173)." Available online: http://www.regeringen.se/49bba6/contentassets/ f213f430f0a346439fbbf31af880718e/en-samlad-naturvardspolitik-skr.200102173 (accessed on 16 March 2017).

39. Jordbruksdepartmentet (Ministry of Agriculture). “Det Går Långsamt Fram: Jämställdhet Inom Jord-Och Skogsbrukssektorn. Ds.2004:39." 2004. Available online: http://www.regeringen.se/rattsdokument/ departementsserien-och-promemorior/2004/08/ds-200439/ (accessed on 16 March 2017).

40. Arora-Jonsson, Seema. "Discordant connections: Discourses on gender and grassroots activism in two forest communities in India and Sweden." Signs 35 (2009): 213-40. [CrossRef]

41. Regeringskansliet. Konkurrenskraft kräver jämställdhet: Jämställdhetsstrategi för skogsbrukssektorn. Edited by Landsbygdsdepartmentet. Stockholm: Regeringskansliet, 2011.

42. Hulme, Mike. "Problems with making and governing global kinds of knowledge." Global Environmental Change 20 (2010): 558-64. [CrossRef] 
43. Buckingham, Susan. “Call in the women." Nature 468 (2010): 502. [CrossRef] [PubMed]

44. Arora-Jonsson, Seema. "Virtue and vulnerability: Discourses on women, gender and climate change." Global Environmental Change 21 (2011): 744-51. [CrossRef]

45. Jasanoff, Sheila. “Technologies of humility.” Nature 450 (2007): 33. [CrossRef] [PubMed] 